\title{
THE EFFECT OF LOCAL GOVERNMENT OWN REVENUE AND REVENUE SHARING FUNDS ON ECONOMIC PERFORMANCE AND COMMUNITY WELFARE THROUGH CAPITAL EXPENDITURE OF REGENCY / CITY IN BALI PROVINCE, INDONESIA
}

\author{
Lestari Sri, Utama Made Suyana \\ Master's Program of Economics, University of Udayana, Bali, Indonesia \\ E-mail: tirtayaniayu@gmail.com
}

\begin{abstract}
The consequence of implementing regional autonomy in Indonesia is the adequate financial capacity of regional governments to improve service to improve welfare for the community. The non-leveling of financial resources and regional economic potential causes an imbalance in the level of welfare between regions. The purpose of this study is to analyze: 1) the effect of local government own revenue and revenue sharing funds on capital expenditure, 2) the influence of local government own revenue, revenue sharing funds, and capital expenditure on economic performance, 3) the influence of local government own revenue, revenue sharing funds, capital expenditure, and economic performance on the community welfare, and 4 ) the effect of local government own revenue, revenue sharing funds on the community welfare through capital expenditure and economic performance of Regency / cities in Bali Province. This study uses secondary data in the form of panel data during the years 2010 2017 of Regency / cities in Bali Province. Data collected is data on Local Government Own Revenue (PAD), Revenue Sharing Funds (DBH), Capital Expenditures obtained from the Bali Provincial Finance Bureau, and data on per capital income and Human Development Index (HDI) obtained from the Provincial Statistics Agency (BPS) Office Bali. The data is then analyzed by path analysis using Partial Leas Square (PLS) software. This study concludes that local revenue has a positive effect on capital expenditure, but revenue-sharing funds have no significant effect on regency / cities in Bali Province during 2010 - 2017. Local government owns revenue, revenue sharing and capital expenditure have a positive effect on economic performance. Local government owns revenue, revenue sharing funds, capital expenditure, and economic performance have a positive effect on the community welfare. Local government own revenue, revenue sharing funds affect the community welfare through capital expenditure and economic performance of Regency/cities in Bali Province. With the imbalance of the Community welfare in the Province of Bali, it is recommended that the central government increase the balance funds for regency/cities whose HDI is still low.
\end{abstract}

\section{KEY WORDS}

Regional local government own revenue, revenue sharing funds, capital expenditure, economic performance, community welfare.

The aim of implementing regional autonomy in Indonesia is administratively so that local governments in carrying out their duties and functions try to achieve efficient and effective and more responsible (Suwandi, 2000). With the government getting closer to the community, regional autonomy is expected to accelerate the improvement of the welfare of the people in the regency / cities. Community welfare in a region can be seen from the Human Development Index (HDI). Thus the region can improve the welfare of the community through increasing human development as reflected in the increasing Human Development Index (HDI).

$\mathrm{HDI}$ is a composite index to regulate the achievement of the quality of human development to live a better quality, both in terms of health, education and economics (Christy and Priyo Hari Adi, 2009). Health indicators are measured using life expectancy. Educational indicators are measured by literacy and school length variables which are assumed to be able to describe the ability of human resources to find and utilize knowledge 
and technology. Economic indicators are approached by household expenditure variables as a proxy for household income to meet minimum living needs, while the quality of housing can describe the level of occupancy and welfare of the community. Achievement of HDI in Bali Province in 2010-2017 is presented in Figure 1.

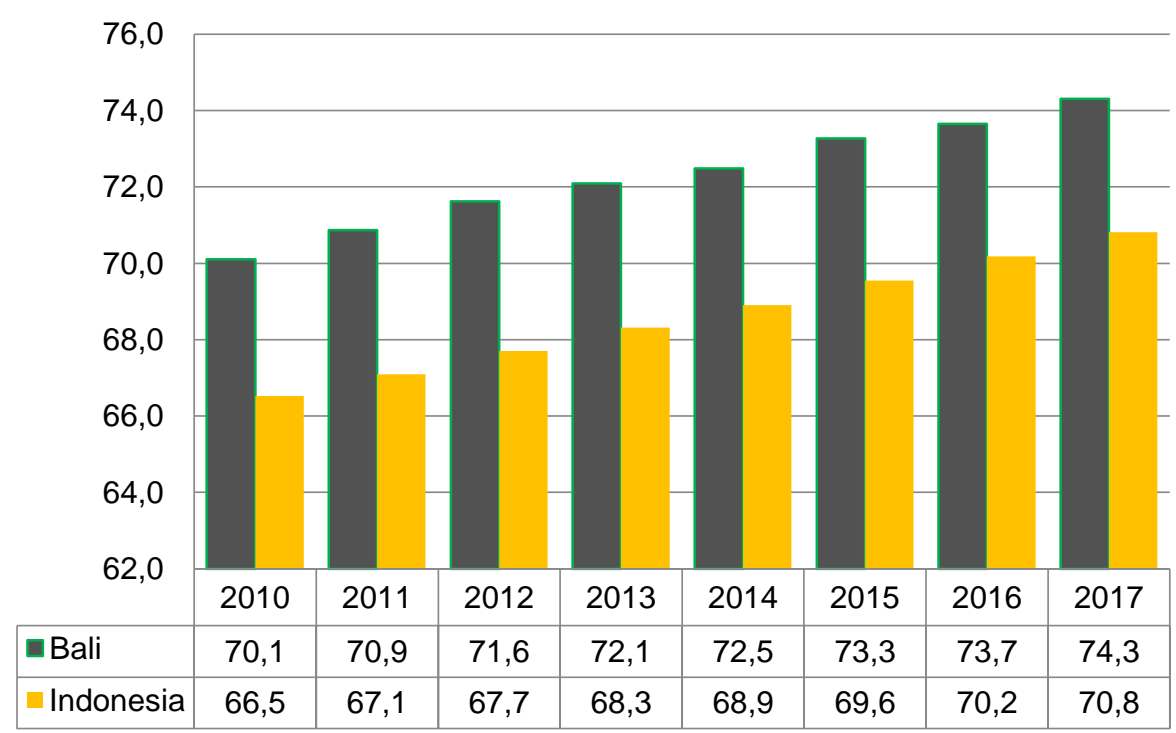

Figure 1 - Human Development Index (HDI) in the provinces of Bali and Indonesia, 2010-2017

Based on Figure 1 it can be seen that HDI in Bali Province is far above the national average, because from 2010 to 2017 Bali Province HDI is ranked fifth out of 34 provinces in Indonesia. As explained earlier HDI in Bali Province is above the national average. However, if viewed by regency / city, the HDI achievement shows inequality. As presented in Figure 2, the Sarbagita area (Denpasar, Badung, Gianyar, and Tabanan) has HDI achievement above the average of regencies / cities in Bali Province.

The difference in HDI between regency / cities is certainly caused by differences in the resources possessed by each region. The resources referred to include sources of development funds and good services obtained from the central government, as well as those obtained from the region itself and its allocation, as well as economic conditions. As it is known that HDI is measured based on the performance of education, health, and economy, then in the context of implementing regional autonomy this is closely related to the availability of government budgetary resources to support education, health and economic services. The greater the budget allocated for education, health and economic programs, the better the HDI in an area. As stated by Suwandi (2000) that the capacity of the Regional Government in carrying out functions such as implementing a public service function, carrying out a development function and implementing a protective function is regional financial capacity. The low financial capacity of the region will often lead to a negative effect cycle, namely the low level of service for the community making it difficult to improve their welfare. Besides being related to the budget, $\mathrm{HDI}$ is also related to the economic performance of a region.

In terms of regional expenditures that are directly related to improving community welfare and growing economic activities, capital expenditure is needed. According to Bastian (2006) capital expenditure is allocated for expenditures relating to the purchase of investment goods in the form of fixed assets and other assets, or certain facilities in order to provide services to the public directly or indirectly the benefits of the community. This capital expenditure is based on regional needs for infrastructure, both for the smooth implementation of government duties and for public facilities, such as equipment, buildings, infrastructure, such as education, health facilities, roads, bridges, irrigation facilities, and others. Because capital expenditure is very important for service to the community, improving 
economic performance and public welfare, the central government requires regions to budget for Capital Expenditures of at least 20 percent of the total Regional Expenditure each year.

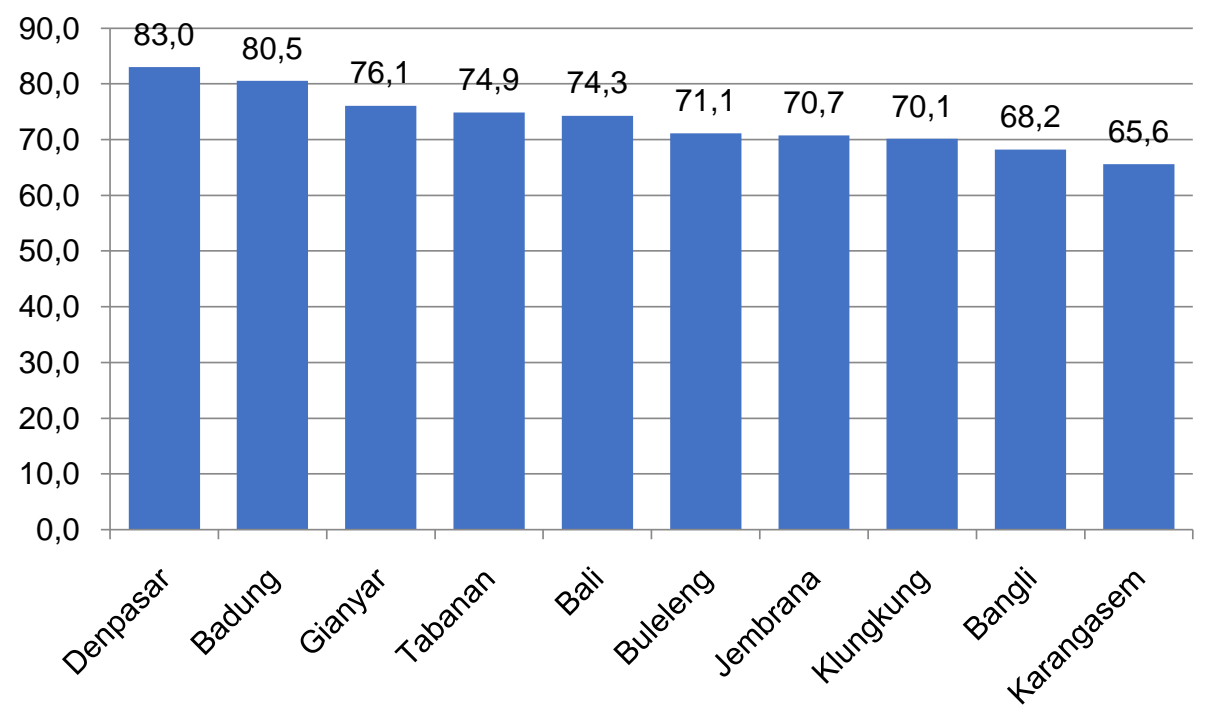

Figure 2 - Human Development Index (HDI) of Regency / Cities in Bali Province In 2017

The results of the Denni Sulistio Mirza (2012) study concluded that capital expenditure and economic growth had a positive effect on the HDI. Likewise, the research of Sumanto and Effendie (2015) concluded that capital expenditure and private investment had a significant effect on the welfare of the people in the regency / cities in East Java Province.

In the context of implementing regional autonomy, the regional government gets several sources of income from the central government in the form of balance funds such as the General Allocation Fund (DAU), Special Acolation Funds (DAK), Revenue sharing Funds $(\mathrm{DBH})$, and other funds. In addition, the regions have the authority to explore financial resources from their own regions, which are called Local government own revenue (PAD). The financial resources mentioned in accordance with the law have their own designation in order to finance development and service to the community.

Revenue sharing funds (DBH) as one component of the balance fund is funds originating from the revenues of the State Budget (APBN) allocated to regions based on certain percentage figures to fund regional needs in the context of implementing decentralization (Ahmad, 2002). DBH transferred by the central government to the regional government consists of two types, namely the revenue sharing fund and non-tax revenuesharing (natural resources). Regions that have natural wealth and tax revenues will have regional revenues derived from the results of the management of these sources by the central government to finance their regional expenditures (Nazarullah, 2011). The results of the management of these resources are allocated to the regions in the form of (DBH) using the principle of origin (the producing region) and seeing the realization in the APBN.

$\mathrm{DBH}$ is a component of balance funds originating from APBN revenues and allocated to regions based on a certain percentage to fund regional needs in the context of implementing decentralization. As stated by Saragih (2003), revenue sharing funds act as a fiscal balance between the center and the regions from the tax that is divided. According to Pipin Syarifin and Dedah Jubaedah (2005) Revenue sharing funds are funds sourced from the state budget allocated to regions based on percentage figures to fund regional needs in the context of implementing decentralization. Previous studies related to DBH were conducted by Aris Setia Budi (2017) in her research at the Regency / City in Central Java in 2012-2014, stating that the Revenue sharing fund (DBH) had a positive effect on the HDI, but was not significant. Nonetheless, the Revenue sharing Fund (DBH) also has an influence on regional government spending. The results of a study conducted by Wulandari (2014) in his 
research entitled The Effect of Revenue Sharing on Regional Expenditures of Regency and Cities in Indonesia concluded that Revenue sharing funds had a significantly positive effect on regional expenditure.

Other factors that influence the HDI are Local government own revenue (PAD), capital expenditure, and economic growth. Several previous studies regarding, among others, those conducted by Mahendra Putra and Agung Ulupui (2015) showed that Local government own revenue (PAD) had a significant positive effect on HDI of Regency / cities in Bali Province. As stipulated in Law Number 33 of 2004, concerning the Balance of Central and Regional Finance, that in the implementation of regional autonomy, the regions have the authority to explore sources of income in the area called Local Government Own Revenues (PAD). Therefore, in regional autonomy, the regional government is expected to optimize the utilization of its regional potential to be extracted as a source of PAD which is then used to finance development and service to the community in the form of capital expenditure so that welfare increases.

The influence of PAD on capital expenditure can be seen from the research of Novia Nur Putriasani (2010). The study concluded that the greater the PAD of a region, the greater the capital expenditure that can be allocated. Likewise, the results of the research of Denni Sulistio Mirza (2012) concluded that increasing PAD had a positive influence on capital expenditure. The relationship between PAD and capital expenditure can also be seen in the study of Dedi Suprianto (2016) with the title "Effect of Local government own revenue (PAD) on Government Capital Expenditures in Nagan Raya Regency". The study concluded that PAD has a positive effect on capital expenditure. This means that the higher the PAD, the higher the capital expenditure.

Economic conditions are important indicators in the calculation of HDI. The relationship of economic growth to HDI can be seen from the results of the research of Asmita et al. (2017). The results of the study stated that increasing per capita income led to increased public access to education and health so that people's welfare also increased.

Local government own revenue (PAD) also affects economic growth. With the more flexible nature of use, the greater the PAD owned by a region, the greater the economic growth. This can be seen from the research of Hammond and Mehmet S. Tosun (2009) which concluded that decentralization or autonomy reflected by regional financial independence or the ratio between PAD and APBD had a positive impact on economic growth, especially the growth of employment and regional income growth in America. Union.

Capital expenditure in the APBD is a component of spending that is very important for economic growth. Because the realization of capital expenditure implemented by the regional government will have a multiplier effect to drive the wheels of the regional economy. Therefore, the higher the capital expenditure ratio in the APBD structure, the better the effect on the economic performance will be. Conversely, the lower the ratio, the smaller the effect on economic growth. The increase in capital expenditure aims to improve economic performance and also the welfare of the community. According to McEachern (2000) that economic performance indicators are the average income generating society, in addition to the number of workers, the number of production, the number of companies, unemployment, inflation, and others. For regional scale, per capita Gross Regional Domestic Product (GRDP) is the most frequently used economic performance indicator. Guritno (2012) also said that increasing government revenues would encourage the government to increase its expenditure in providing services to the community so that incomes would increase, unemployment and poverty would decrease.

The influence of capital expenditure and PAD on economic growth was examined by Azis (2016). The results of the analysis show that Non-Tax / Natural Resources Revenue Sharing Funds, General Allocation Funds and Local government own revenue simultaneously have a significant effect, and only partially Local Government Own Revenues that have a significant and dominant effect on Economic Growth in Malinau Regency. Likewise, Sondakh et al. (2017) who concluded that there is a positive and significant relationship between government and private investment in increasing employment opportunities and economic growth in the city of Manado. Guritno (2012) also said that 
increasing government revenues would encourage the government to increase its expenditure in order to improve economic performance.

Based on the description above this study aims at the Influence of Local Government Own Revenue (PAD) and Revenue sharing Funds (DBH), capital expenditure on economic performance and the community welfare (HDI) in regencies / cities in Bali Province.

\section{LITERATURE REVIEW}

Economic performance in a region according to McEachern (2000: 84) can be done in various ways, among others, by looking at the number of workers, average income, total production, number and size of the company. In addition, a measure of economic performance that is often a concern for knowing economic progress in a region or country is economic growth and labor, productivity, living standards, unemployment, inflation, savings and capital formation, and other variables (Abel and Bernake, 2001).

According to Samuelson and Nordhaus (1995) among the benchmarks of economic performance, the most commonly used is Gross Domestic Product (GDP). While GDP itself is defined as the value of goods and services produced in an area of the economy for a certain period of time, generally one year. Gregory and Stuart (1992: 41) suggest that one of the dominant variables used to determine economic performance is the level of economic growth over time. If the production of goods and services produced from time to time has increased, it can be said that the economy is experiencing growth. And to measure economic growth can use GDP values at constant prices (Rahardja and Manurung, 2001: 178).

Local Government Own Revenue, here referred to as PAD is income obtained by regions collected under regional regulations in accordance with laws and regulations". PAD is regional income originating from the results of regional taxes, proceeds from regional levies, the results of separated regional wealth management, and other legitimate local revenue, which aims to provide flexibility to the regions in exploring funding for the implementation of regional autonomy as a manifestation of the decentralization principle (Explanation of Law No.33 of 2004).

PAD is a source of regional income originating from economic activities in the area concerned based on applicable regulations. The types of PAD are classified into 4 (four), namely funds from local tax collection, funds from regional levies collection fees, funds from separated regional wealth management and other legitimate PAD. According to Warsito (2001: 128) Local Government Own Revenue "Local government ownrevenue(PAD) is income that is sourced and collected by the local government. The source of PAD consists of: local taxes, regional retribution, profits from regionally-owned enterprises (BUMD), and other legitimate local revenue". Herlina Rahman (2005: 38) Local government own revenue is regional income originating from the results of regional taxes, the results of the distribution of separated regional wealth management results and other legitimate local revenue in exploring funding in the implementation of autonomy as a manifestation of the principle of decentralization.

Regional financial policy is directed at increasing local government own revenue as the main source of regional income that can be used by regions in implementing regional government and development in accordance with their needs in order to minimize dependence on obtaining top-level funds and government (subsidies). Thus the effort to increase PAD should be seen from a broader perspective not only in terms of each region but also in relation to the unity of the Indonesian economy. PAD itself, is considered as an alternative to obtain additional funds that can be used for various expenditure needs determined by the region itself, especially routine needs. Therefore the increase in income is something that is desired by each region (Mamesa, 1995: 30).

Based on Law Number 33 of 2004 of Indonesian Republic, concerning Financial Balance Between the Center and Regions, "Regional Government Own Revenue, referred to as PAD is income obtained by regions collected under regional regulations in accordance with laws and regulations". PAD is regional income originating from the results of regional taxes, proceeds from regional levies, the results of separated regional wealth management, 
and other legitimate local revenue, which aims to provide flexibility to the regions in exploring funding for the implementation of regional autonomy as a manifestation of the decentralization principle (Explanation of Law No.33 of 2004).

$P A D$ is a source of regional income originating from economic activities in the area concerned based on applicable regulations. The types of PAD are classified into 4 (four), namely funds from local tax collection, funds from regional levies collection fees, funds from separated regional wealth management and other legitimate PAD. According to Warsito (2001: 128) Local Government Own Revenue "Local government own revenue (PAD) is income that is sourced and collected by the regional government. The source of PAD consists of: regional taxes, regional retribution, profits from regionally-owned enterprises (BUMD), and other legitimate local revenue ". Herlina Rahman (2005: 38) Local government own revenue is regional income originating from the results of regional taxes, the results of the distribution of separated regional wealth management results and other legitimate local revenue in exploring funding in the implementation of autonomy as a manifestation of the principle of decentralization.

Regional financial policy is directed at increasing Local government own revenue as the main source of regional income that can be used by regions in implementing regional government and development in accordance with their needs in order to minimize dependence on obtaining top-level funds and government (subsidies). Thus the effort to increase PAD should be seen from a broader perspective not only in terms of each region but also in relation to the unity of the Indonesian economy. PAD itself, is considered as an alternative to obtain additional funds that can be used for various expenditure needs determined by the region itself, especially routine needs. Therefore the increase in income is something that is desired by each region (Mamesa, 1995: 30).

Sources of local government own revenue are:

a) Regional Tax

b) Regional Retribution;

c) Results of Management of the Wealth of Separated Regions

d) Legitimate Other PAD

Other's sources of regional government's revenue according to Law Number 33 of 2004 concerning Financial Balance between the Central Government and Regional Governments, Balancing Funds are funds originating from APBN revenues allocated to the regions to fund regional needs in the context of implementing decentralization. There are types of balancing funds, namely Revenue sharing Funds (DBH), General Allocation Funds (DAU), and Special Allocation Funds (DAK).

According to Law Number 33 of 2004 article 11, it is stated that Revenue Sharing Funds $(\mathrm{DBH})$ are regional funds including taxes and natural resources. Taxes in this case consist of land and building tax, income tax article 25 and article 29 domestic taxpayers and article 21 income tax, and fees for acquiring land and building rights. But starting on January 1,2014 , for land and building taxes collected by the region. Natural resources consist of forestry, general mining, fisheries, oil mining, natural gas mining and geothermal mining.

In connection with the holding of regional autonomy, the regions need to use funds effectively and efficiently to carry out government and regional development, one of which is by allocating them to capital expenditure. According to Halim (2007) capital expenditure is budget expenditure to obtain fixed assets and other assets that provide benefits for more than one accounting period. According to Bastian (2006), capital expenditure is allocated to accommodate all expenditures related to the purchase of goods for investment needs (in the form of fixed assets and other assets). Capital expenditures made by local governments are intended to procure investment goods or certain facilities in order to provide services to the community directly or indirectly the benefits of the community. Capital expenditure used by Regional Government according to SAP, includes land expenditure; shopping for equipment and machinery; shopping for buildings and buildings; road, irrigation and network shopping; other fixed assets expenditure; and other asset expenditure.

According to Halim (2004), capital expenditure is a expenditure whose benefits exceed one fiscal year and will increase regional assets or wealth and will increase routine 
expenditures such as maintenance expenditures. Capital expenditure based on needs means that not all work units or organizational units in the regional government carry out activities or projects to procure fixed assets. In accordance with the main tasks and functions (tupoksi) of each work unit, there is a work unit that provides public servants in the form of provision of physical facilities and infrastructure, such as education, health facilities, roads, bridges, irrigation facilities, etc. Other work only provides direct services in the form of administrative, security, empowerment, health services and education services.

The United Nations Development Program (UNDP) through its serial publications since the early 1990s measured the success of development in a more comprehensive manner using life expectancy, education, and income constructed into the Human Development Index = HDI (Todaro, 2002 ) Thus, the welfare state is a composite index of indicators of health, education and economy. Health indicators are measured using life expectancy. Educational indicators are measured by literacy and school length variables which are assumed to be able to describe the ability of human resources to find and utilize knowledge and technology. Economic indicators are approached by household expenditure variables as a proxy for household income to meet minimum living needs, while the quality of housing can describe the level of occupancy and welfare of the community.

The UNDP version of the HDI calculation is intended to measure the impact of efforts to improve basic capabilities, using impact indicators as a basic component of calculation, namely life expectancy at birth, educational attainment measured by literacy and average length of school, and adjusted income. The HDI scale is between 0 - 1 , the closer to number 1, the better the human development. Indonesia Central Statistic Agency (BPS) has a slightly different calculation with UNDP, BPS version of HDI is based on three categories namely, (1) longevity is reflected in the life expectancy index (index X1); (2) Educational attainment measured by a combination of literacy rates and average length of school (index X2); (3) standard of living measured by the per capita consumption expenditure approach in rupiah PPP (index X3). The HDI scale is between 1 and 100. The closer the HDI value of a region to the number 100 the closer the road must be taken to reach the target. The full HDI calculation is as follows:

$$
\mathrm{HDI}=1 / 3(\text { index } X 1+\text { index X2 }+ \text { index X3) (1) }
$$

Where: $\mathrm{X} 1$ = Life Expectancy Index; $\mathrm{X} 2$ = Education Index; $\mathrm{X} 3=$ Per capita Expenditure Index; $X 2=2 / 3$ (literacy index) $+1 / 3$ (average length of school index).

\section{METHODS OF RESEARCH}

The design of the research is the design, guidance or reference of the research that will be carried out, therefore the design of the research must contain everything that has an interest in the conduct of research (Bungin, 2001). According to the type of data and analysis techniques, this research is quantitative research, which is the type of research that is based on quantitative data or its findings are achieved using statistical procedures or other quantifications. The types of data collected are secondary data, namely data on Local Government Own Revenue (PAD), Revenue Sharing (DBH), capital expenditure, Economic Performance, and HDI for 2010-2017. The data analysis technique used in this study is path analysis / path analysis to determine the effect of PAD and Revenue Sharing Funds, capital expenditures, economic performance on the welfare of the community in regencies / cities in Bali Province, as illustrated in Figure 3.

Operational Definition of Research Variables:

- Local Government Own Revenue is regional revenue derived from the ability of the region itself to manage its sources of income based on the regional regulations themselves. In this study Local Government Own Revenue was obtained from the realization of Regency / City APBD in the Province of Bali divided by the number of population in the Regency / City in the Province of Bali during 2010 to 2017 in units of Rupiah (Rp); 
- Revenue Sharing Funds. Because the Province of Bali does not have natural resources, the Revenue Sharing Fund is a transfer fund from the central government originating from state revenues from taxes such as Income Tax Article 21 Income Tax and Income Tax Article 25/29, PBB, and BPHTB. This study uses the variable Realization of Tax Revenue Funds obtained from the realization of the APBD divided by the number of residents in the Regency / City in the Province of Bali during the years 2010 to 2017 in units of Rupiah;

- Capital Expenditures. Capital expenditure is expenditure carried out by the Regional Government in accordance with the needs and or priorities of the region to obtain fixed assets or other assets in order to improve facilities and infrastructure that support services to the community. In this study Capital Expenditures are obtained based on the realization of Capital Expenditures divided by the number of residents in the Regency / City in the Province of Bali during 2010 to 2017 in units of Rupiah;

- Economic Performance. Economic performance in this study uses the Gross Regional Domestic Product (GRDP) per capita calculated by dividing the GRDP data by the population in the Regency / City in the Province of Bali during 2010 to 2017 in units of Rupiah;

- Community Welfare. The welfare of the community in this study uses the Human Development Index (HDI) which is a composite index to regulate the achievement of the quality of human development to live more quality, both in terms of health, education and economics, measured in index units.

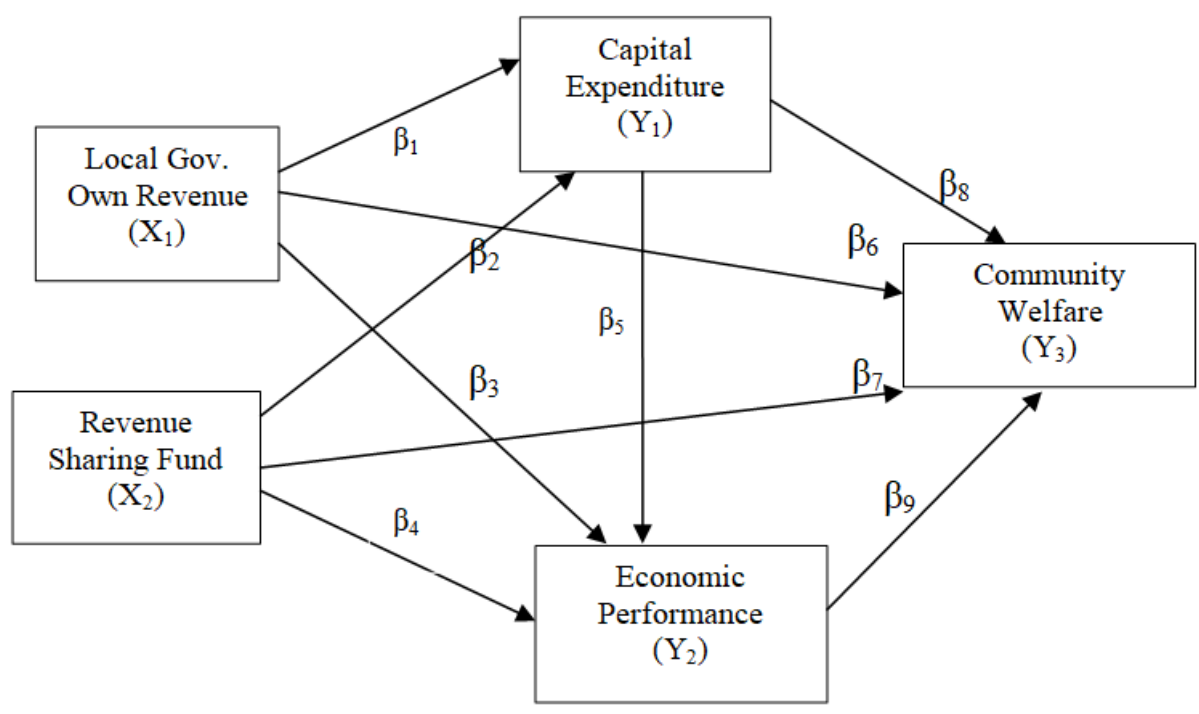

Figure 3 - Research Design Effects of Local Government Own Revenue and Revenue sharing funds on Capital Expenditures, Economic Performance and Community Welfare of Regency / Cities in Bali Province

This study uses quantitative data, namely data in the form of numbers obtained from secondary sources, namely data on Local government own revenue (PAD), Tax Revenue Funds (DBH), and Capital Expenditures obtained from the Bali Provincial Finance Bureau, while Performance Economics and HDI were obtained from the Central Bureau of Statistics of Bali Province during 2010-2017. Thus this study uses panel data which is a combination of cross section data, namely data of regency / cities in Bali Province with time series data during 2010-2017.

The analysis technique used in this study is path analysis using Partial Least Square (PLS). Path analysis is an extension of the application of multiple linear regression analysis to predict causality relationships between variables (casual models) that have been predetermined based on theory. This model is considered to be used in a study if the relationship analyzed is a causal relationship with a complex model. In path analysis there is 
a variable that has a dual role, namely as an independent variable in a relationship, but becomes a dependent variable in another relationship. This form of relationship requires an analytical tool that is able to explain the system simultaneously. Kerlinger (2002) states that using path analysis can be calculated directly and indirectly between variables.

Based on Figure 3, a structural equation system can be made as follows.

Relationship between X1 and X2:

$$
Y 1=\beta 1 X 1+\beta 2 X 1+\varepsilon 1
$$

Relationship between $\mathrm{X} 1$ and $\mathrm{X} 2$ to $\mathrm{Y} 1$ :

$$
Y 2=\beta 3 X 1+\beta 4 X 2+\beta 5 Y 1+\varepsilon 2
$$

Relationship between $\mathrm{Y} 1, \mathrm{Y} 2$ towards $\mathrm{Y}$ :

$$
Y 3=\beta 6 X 1+\beta 7 X 2+\beta 8 Y 1+\beta 9 Y 2+\varepsilon 3 \text { (3) }
$$

Where: X1 = Local Government Own Revenue per capita (Rp); X2 = Realization of Revenue sharing Funds per capita (Rp); X3 = Capital expenditure per capita (Rp); Y1 = Economic Performance or GRDP per capita (Rp); Y2 = Community Welfare / HDI (index); $\beta$ 1, $\beta 2 \ldots B 9$ is the path coefficient; $\varepsilon 1, \varepsilon 2 \ldots \varepsilon 3$ is a error,

\section{RESULTS AND DISCUSSION}

Bali Province is one of 33 provinces in Indonesia which has an area of 5,636.66 km2 or 0.29 percent of Indonesia's territory. Bali Province consists of one main island, namely Bali Island and several other small islands, such as Nusa Penida Island, Nusa Ceningan Island, Nusa Lembongan Island, Serangan Island and Menjangan Island. Administratively, the Province of Bali is divided into 8 Regencies, 1 City, 57 Regency, 715 Villages, 1,482 Pekraman villages, and 1,604 subak sawahs and 1,107 sub-villages. Area if divided according to regency / city, Buleleng Regency has the largest area of $1,365.88 \mathrm{~km} 2$, and the smallest is Denpasar City with an area of $127.78 \mathrm{~km} 2$.

The following will be described regarding the research variables used in the study, namely Local government own revenue (PAD), Revenue sharing funds (DBH), Capital Expenditures, Economic Growth and HDI.

Local Government Own Revenue (PAD) is revenue obtained from the region itself, which consists of: a) regional tax, b) regional retribution, c) from the wealth of the region whose management is separated, and d) others that are legal. To be able to compare PAD of an area with other regions which will later be used to finance services and development, it is divided by the total population.

Table 1 - PAD per Capita Regency / City in Bali Province, 2010-2017 (Thousands of Rupiah)

\begin{tabular}{lllllllll}
\hline Regency/City & 2010 & 2011 & 2012 & 2013 & 2014 & 2015 & 2016 & 2017 \\
\hline Jembrana & 128.08 & 140.23 & 196.53 & 237.04 & 259.48 & 294.58 & 368.66 & 435.64 \\
Tabanan & 255.71 & 305.68 & 387.65 & 471.49 & 517.33 & 605.65 & 695.37 & 894.77 \\
Badung & $2,251.08$ & $2,723.50$ & $3,161.16$ & $3,445.10$ & $4,107.86$ & $4,594.47$ & $5,071.97$ & $6,617.59$ \\
Gianyar & 279.28 & 378.32 & 473.94 & 541.69 & 716.04 & 825.85 & $1,013.87$ & $1,323.36$ \\
Klungkung & 181.43 & 199.48 & 227.61 & 341.92 & 483.40 & 568.11 & 690.32 & 830.30 \\
Bangli & 79.69 & 100.09 & 178.33 & 210.13 & 298.24 & 395.33 & 460.23 & 521.99 \\
Karangasem & 138.96 & 300.44 & 320.07 & 391.15 & 498.60 & 568.17 & 559.24 & 436.54 \\
Buleleng & 123.48 & 160.20 & 181.11 & 226.60 & 325.75 & 409.50 & 485.35 & 722.13 \\
Denpasar & 268.33 & 405.90 & 487.11 & 693.64 & 745.85 & 822.73 & 825.29 & $1,020.13$ \\
\hline
\end{tabular}

Source: Financial Bureau Province of Bali, 2018.

Table 1 shows the PAD per capita in regencies / cities in Bali Province during 2010 2017. In general, Regency / City PAD in Bali Province is still uneven and tends to have 
unbalanced capabilities as shown in Table 1 where regions have a lot of potential tourism, obtaining high PAD while those with limited tourism potential receive small PAD. This certainly will have an impact on development in the area concerned. However, from year to year all regency / cities experienced an increase in PAD, such as Jembrana Regency in 2010 per capita PAD of Rp. 128,080.00 increased to Rp.435,350.00 in 2017.

Revenue sharing funds transferred by the central government to regional governments consist of two types, namely the revenue sharing fund and non-tax revenue-sharing (Natural Resources). In Table 2 shows that from 2010 to 2017 the Badung Regency and Denpasar City received the largest revenue-sharing funds due to the high investment transactions which resulted in high payments for land and building taxes, so that Badung Regency and Denpasar City were allocated high Revenue sharing Funds. In addition, Revenue sharing funds obtained by the governments of Buleleng and Denpasar City decreased from 2016 to 2017.

Table 2 - Regency / City Per Capita Revenue sharing Funds in the Province of Bali, 2010-2017 (Thousands of Rupiah)

\begin{tabular}{lllllllll}
\hline Regency / City & 2010 & 2011 & 2012 & 2013 & 2014 & 2015 & 2016 & 2017 \\
\hline Jembrana & 103.16 & 79.56 & 92.84 & 82.20 & 72.04 & 79.63 & 81.10 & 93.75 \\
Tabanan & 83.05 & 62.55 & 70.60 & 52.57 & 55.52 & 57.00 & 58.83 & 70.23 \\
Badung & 400.21 & 206.04 & 159.66 & 104.05 & 98.67 & 115.03 & 134.21 & 133.92 \\
Gianyar & 70.15 & 48.86 & 60.16 & 84.46 & 52.66 & 54.24 & 58.43 & 61.55 \\
Klungkung & 121.17 & 98.53 & 115.90 & 117.50 & 102.00 & 113.95 & 115.49 & 139.46 \\
Bangli & 102.91 & 85.50 & 100.17 & 100.82 & 78.49 & 89.54 & 87.26 & 101.95 \\
Karangasem & 63.79 & 55.08 & 65.42 & 72.69 & 54.05 & 59.61 & 56.61 & 69.68 \\
Buleleng & 81.50 & 62.48 & 61.76 & 63.35 & 54.13 & 56.72 & 50.54 & 44.47 \\
Denpasar & 152.48 & 112.82 & 139.80 & 88.22 & 80.43 & 90.61 & 108.37 & 105.90 \\
\hline
\end{tabular}

Source: Financial Bureau Province of Bali, 2018.

The allocation of capital expenditure for Bali Province and regency / city in Bali is very fluctuating for each year, this is due to lack of knowledge of the impact of capital expenditure on community economic growth so that the attention of local governments does not have a provision in allocating capital expenditure in regional income and expenditure budgets. Therefore it is deemed necessary by the Central Government to emphasize the obligation for regions to budget Capital Expenditures of at least 20 percent of the total Regional Expenditures for each guideline for annual budget and expenditure.

Table 3 - Regency / City per capita Capital Expenditures in Bali Province, 2010-2017 (Thousands of Rupiah)

\begin{tabular}{lllllllll}
\hline Regency / City & 2010 & 2011 & 2012 & 2013 & 2014 & 2015 & 2016 & 2017 \\
\hline Jembrana & 303.20 & 372.76 & 553.38 & 571.92 & 641.56 & 731.27 & 1301.94 & 1273.22 \\
Tabanan & 255.88 & 231.93 & 348.51 & 325.41 & 341.49 & 287.68 & 634.13 & 1185.72 \\
Badung & 511.84 & 571.97 & 1293.35 & 1445.92 & 1811.15 & 1797.48 & 2285.53 & 2297.90 \\
Gianyar & 279.53 & 258.91 & 284.53 & 408.72 & 462.33 & 447.60 & 735.12 & 868.73 \\
Klungkung & 441.10 & 533.08 & 578.05 & 539.99 & 712.04 & 800.67 & 1398.74 & 1186.18 \\
Bangli & 400.76 & 581.17 & 410.90 & 334.36 & 401.40 & 592.10 & 1406.28 & 1133.39 \\
Karangasem & 300.41 & 384.19 & 536.31 & 485.58 & 514.58 & 511.67 & 629.07 & 718.19 \\
Buleleng & 154.93 & 261.52 & 224.54 & 340.18 & 348.50 & 362.27 & 627.06 & 513.76 \\
Denpasar & 104.80 & 129.95 & 291.43 & 356.31 & 353.45 & 274.89 & 328.76 & 353.92 \\
\hline
\end{tabular}

Source: Financial Bureau Province of Bali, 2018.

In Table 3, we can see the description of capital expenditure in 2010-2017 in the three regency / city governments in Balir, the capita capital expenditure in Badung, Jembrana, and Klungkung Regency is quite large. Badung Regency is Rp.2,297,900.00, Jembrana Regency Rp.1,273.220.00.00 and Klungkung Regency Rp.1,186,180.00. In 2017, it can be seen that the capital expenditure per capita of regencies / cities in the province has increased compared to the previous year except Buleleng Regency which experienced a decrease in 
capital expenditure, namely in 2016 the capital expenditure per capita was Rp. $627,060.00$ to Rp. 513,760.00 in 2017.

According to McEachern (2000) that economic performance indicators are the average income generating society, in addition to the number of workers, the number of production, the number of companies, unemployment, inflation, and others. For regional scale, per capita Gross Regional Domestic Product (GRDP) is the most frequently used economic performance indicator. Table 4 shows the per capita GRDP of regencies / cities in Bali Province during 2010 - 2017. The highest per capita GRDP is owned by Badung Regency, and then followed by Denpasar City. The region with the lowest per capita GRDP is Karangsem Regency.

Table 4 - Regency / City GRDP Per Capita at Constant Prices 2010 in Bali Province, 2010-2017 (Millions of Rupiah)

\begin{tabular}{lllllllll}
\hline Regency / City & 2010 & 2011 & 2012 & 2013 & 2014 & 2015 & 2016 & 2017 \\
\hline Jembrana & 21.57 & 23.81 & 26.19 & 28.99 & 33.43 & 37.83 & 40.95 & 44.40 \\
Tabanan & 22.08 & 24.36 & 26.81 & 30.11 & 34.77 & 39.47 & 42.57 & 46.60 \\
Badung & 38.14 & 41.91 & 47.31 & 53.97 & 61.50 & 66.97 & 74.95 & 81.32 \\
Gianyar & 23.12 & 25.48 & 28.27 & 31.62 & 36.51 & 40.50 & 44.29 & 48.26 \\
Klungkung & 20.92 & 23.06 & 25.44 & 28.18 & 32.47 & 36.50 & 40.33 & 44.25 \\
Bangli & 12.71 & 14.02 & 15.38 & 17.18 & 19.80 & 22.42 & 24.44 & 26.81 \\
Karangasem & 16.97 & 18.61 & 20.47 & 22.99 & 26.53 & 30.10 & 32.74 & 25.53 \\
Buleleng & 21.75 & 24.10 & 26.69 & 29.99 & 34.78 & 39.45 & 42.68 & 46.80 \\
Denpasar & 25.61 & 27.95 & 31.15 & 34.73 & 39.61 & 43.68 & 47.81 & 51.58 \\
\hline
\end{tabular}

Source: Bali Central Statistic Agency, 2018.

Community welfare in this study uses the Human Development Index (HDI) indicator of $\mathrm{HDI}$ is a composite index to regulate the achievement of the quality of human development to live a better quality, both from the aspect of health, education and economics (Christy and Priyo Hari Adi, 2009). The HDI measures the achievements of human development based on a number of basic components of quality of life. As a measure of quality of life, HDI is built through a basic three-dimensional approach. These dimensions include longevity and health, knowledge, and a decent life.

Table 5 shows data on Regency / City HDI in Bali Province in 2010-2017 which increased, namely 70.07 in 2006 to 75.43 in 2017 and it is known that human development in each Regency / City in Bali Province is above the average national level. Based on Table 5.9 it can also be seen that HDI in Bali Province occurs in disparities between regency / cities. In 2010 the first order of HDI was owned by Denpasar City, then followed by Tabanan Regency, while the lowest was Karangasem Regency. In 2017 overall the regency / city HDI experienced an increase accompanied by ranking changes. The city of Denpasar in 2017 is still in first place, and then followed by Badung Regency, and the lowest is still owned by the Regency of Karangasem. In 2010 Buleleng Regency ranked 2nd to 3rd place in 2017. Jembrana Regency in 4th place ranked 5th as the 5th place in 2017.

Table 5 - Regency / City Human Development Index (HDI) in Bali Province, 2010-2017

\begin{tabular}{lllllllll}
\hline Regency / City & 2010 & 2011 & 2012 & 2013 & 2014 & 2015 & 2016 & 2017 \\
\hline Jembrana & 66.70 & 67.53 & 67.94 & 68.39 & 68.67 & 68.67 & 70.38 & 70.72 \\
Tabanan & 70.68 & 71.35 & 71.69 & 72.31 & 72.68 & 72.68 & 74.19 & 74.86 \\
Badung & 75.84 & 76.66 & 77.26 & 77.63 & 77.98 & 77.98 & 79.80 & 80.54 \\
Gianyar & 71.45 & 72.50 & 73.36 & 74 & 74.29 & 74.29 & 75.70 & 76.09 \\
Klungkung & 66.01 & 67.01 & 67.64 & 68.08 & 68.30 & 68.30 & 69.31 & 70.13 \\
Bangli & 63.43 & 63.87 & 64.53 & 65.47 & 65.75 & 65.75 & 67.03 & 68.24 \\
Karangasem & 60.58 & 61.60 & 62.95 & 63.70 & 64.01 & 64.01 & 65.23 & 65.57 \\
Buleleng & 66.98 & 67.73 & 68.29 & 68.83 & 69.19 & 69.19 & 70.65 & 71.11 \\
Denpasar & 79.19 & 79.77 & 80.45 & 81.32 & 81.65 & 81.65 & 82.58 & 83.01 \\
\hline Bali & 70,10 & 70,87 & 71,62 & 72,09 & 72,48 & 73,27 & 73,65 & 74,30 \\
\hline
\end{tabular}

Source: Bali Central Statistic Agency, 2018. 
The structural model in PLS needs to be evaluated for its accuracy by using the Rsquare for the dependent variable and its significance value based on the t-values in each path. The structural model of this research can be seen in Figure 2.

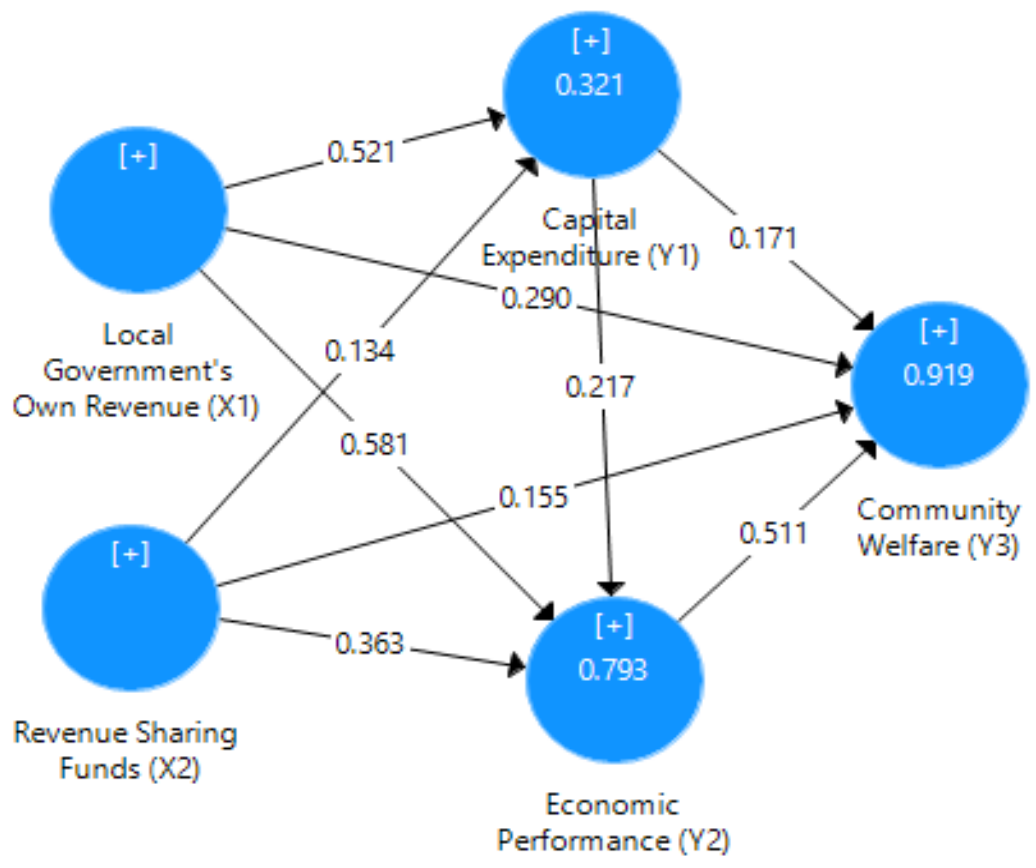

Figure 2 - Path Coefficient of Effect of Local Government Own Revenue and Revenue Sharing Funds on Capital Expenditures, Economic Performance and Community Welfare of Regency / Cities in Bali Province, 2010-2017

Assessing the inner model is the same as looking at the relationship between latent variables by looking at the results of the path coefficient estimation and the significance level. Table 6 shows the R-square value for each endogenous variable. Table 6 shows the $\mathrm{R}$ square value of 0.321 for the capital expenditure variable. It means that the variability of capital expenditure can be explained by the variable PAD and DBH of tax of 32.1 percent, and the remaining 67.9 percent is explained by other factors. Furthermore, the economic performance variable with $\mathrm{R}$-square is 0.793 , meaning that the variable can be explained by the PAD, DBH and capital expenditure variables of 79.3 percent, and the remaining 20.7 percent is explained by factors other than the three. While the R-square value for the HDI variable is 0.919 , which means that the variability of $\mathrm{HDI}$ can be explained by the PAD variable, $\mathrm{DBH}$, capital expenditure, and economic performance by 91.9 percent, and the remaining 8.1 percent is explained by other factors.

Table 6 - R-square value of Variable Capital Expenditure, Economic Performance, and Community Welfare of Regency / Cities in Bali Province, 2010 - 2017

\begin{tabular}{lll}
\hline Variable & R Square & Relationship Criteria \\
\hline Capital Expenditure (Y1) & 0,321 & Moderate \\
Economic Performance (Y2) & 0,793 & Strong \\
Community Welfare (Y3) & 0,919 & strong \\
\hline
\end{tabular}

Source: Research Results.

Chin (1998) categorized R-square into three categories, namely substantial (> 0.67), moderate $(0.33-0.67)$, and weak $(<0.33)$. So that the R-square value for the capital expenditure variable is categorized as moderate, while the $R$-square value for the variable economic performance and public welfare is a strong category. Based on $R^{2}$ in Table 5.10, $\mathrm{Q}^{2}$ or Stone Geiser $\mathrm{Q}$-Square tests can be calculated, namely:

$$
Q^{2}=1-\left\{\left(1-R^{2}{ }_{1}\right)\left(1-R^{2}{ }_{2}\right)\left(1-R^{2}{ }_{2}\right)\right\}=0.989
$$


The result of $Q^{2}$ calculation is 0.989 so that it can be said to have a strong predictive prevalence, so that the resulting model is worthy of being used to predict. The number of 0.989 can be interpreted that the variation of community welfare by 98.9 percent can be explained by variations in the PAD variable, $\mathrm{DBH}$, capital expenditure, and economic performance, while the remaining 1.1 percent is explained by other variables outside the model.

Analysis of direct effects can explain the relationship between variable research (latent variables). To find out the direct effect between variables can be seen from the results of the analysis of the value of the path coefficients shown in Table 7. Based on Table 7, it can be explained that the influence between research variables is positive and significant. Except for the effect of DBH on capital expenditures that are not significant if viewed from the $p$-value greater than 0.05. In other words, PAD has a positive and significant effect on capital expenditure, $\mathrm{PAD}, \mathrm{DBH}$, and capital expenditure, have a positive and significant effect on economic performance, and PAD, DBH, and capital expenditure, and economic performance have a positive and significant effect on the welfare of society.

Table 7 - Direct Inter-Variable Effects of Local Government Own Revenue and Revenue sharing funds on Capital Expenditures, Economic Performance and Community Welfare of Regency / Cities in Bali

Province, 2010-2017

\begin{tabular}{lllll}
\hline Variable Ralationship & Coeffiecient & Std. Deviation & T. Statistic & P. Value \\
\hline X1 $\rightarrow$ Y1 & 0.521 & 0.09 & 5.793 & 0.000 \\
X2 $\rightarrow$ Y1 & 0.134 & 0.082 & 1.628 & 0.104 \\
X1 $\rightarrow$ Y2 & 0.581 & 0.079 & 7.392 & 0.000 \\
X2 $\rightarrow$ Y2 & 0.363 & 0.089 & 4.071 & 0.000 \\
Y1 $\rightarrow$ Y2 & 0.217 & 0.08 & 2.721 & 0.007 \\
X1 $\rightarrow$ Y3 & 0.29 & 0.042 & 6.958 & 0.000 \\
X2 $\rightarrow$ Y3 & 0.155 & 0.045 & 3.459 & 0.001 \\
Y1 $\rightarrow$ Y3 & 0.171 & 0.073 & 2.347 & 0.019 \\
Y2 $\rightarrow$ Y3 & 0.511 & 0.073 & 6.073 & 0.000 \\
\hline
\end{tabular}

Source: Research Results.

Note: $X 1=$ Local Government Own Revenue (PAD); $X 2=$ Revenue sharing Funds $(D B H) ; Y 1=$ Capital Expenditures; $Y 2=$ Economic Performance; $Y 3=$ Community Welfare.

Furthermore, based on the research design, it is also known that there are several relationships which are indirect influences between research variables. To find out the indirect effects between variables can be seen from the results of the indirect effects value analysis shown in Table 8.

Table 8 - Indirect Effects Between Variables of Local Government Own Revenue and Revenue sharing Funds on Capital Expenditures, Economic Performance and Community Welfare of Regency / Cities in Bali Province, 2010 - 2017

\begin{tabular}{llllll}
\hline Variable Ralationship & Melalui & Variable Ralationship & Coeffiecient & Std. Deviation & T. Statistic \\
\hline X1 $\rightarrow$ Y2 & Y1 & 0.113 & 0.042 & 2.707 & 0.007 \\
X1 $\rightarrow$ Y3 & Y1, Y2 & 0.444 & 0.059 & 7.522 & 0.000 \\
X2 $\rightarrow$ Y2 & Y1 & 0.029 & 0.019 & 1.566 & 0.118 \\
X2 $\rightarrow$ Y3 & Y1, Y2 & 0.223 & 0.055 & 4.067 & 0.000 \\
Y1 $\rightarrow$ Y3 & Y2 & 0.111 & 0.041 & 2.699 & 0.007 \\
\hline
\end{tabular}

Source: Research Results.

Note: $X 1$ = Local Government Own Revenue (PAD); X2 = Revenue sharing Funds (DBH); Y1 = Capital Expenditures; Y2 = Economic Performance; Y3 = Community Welfare.

Based on Table 8 it is known that the indirect effect of regional income, revenue sharing funds on the human development index through capital expenditure and economic performance of Regency / cities in Bali Province is significant, with P.Value less than 0.05, but not in influence Direct DBH on economic performance through capital expenditure is not significant. This can be seen from the $p$-value in the relationship of the indirect effect of DBH 
on economic performance through capital expenditure which is worth 0.118 or greater than 0.05 .

\section{DISCUSSION OF RESULTS}

Effect of Local Government Own Revenue (PAD) and Revenue sharing Funds (DBH) on Capital Expenditures of Regency / City in Bali Province. The results of data analysis show that Local Government Own Revenue (PAD) has a positive and significant effect on capital expenditure of Regency / city in Bali Province. This means that the higher the PAD, the allocation for capital expenditure in the Regency / City APBD in the Province of Bali also increases, and vice versa. If PAD decreases, capital expenditure also decreases. As with the case with Revenue sharing Funds (DBH), it does not have a significant effect on capital expenditure. This shows that if the DBH has increased, there is no significant increase in capital expenditure.

As the results of previous research from Priambudi (2017), that PAD turned out to have a positive and significant effect on capital expenditure in Java regency and cities in 2013. Likewise, it was also presented in the results of Pradata's research (2015) that PAD had a positive and significant effect on regency capital expenditure and cities in Central Java in 2011-2013. The results of this study are not in accordance with the results of previous studies from Syahputra (2010) which explained that Production Sharing Funds have a positive and significant correlation in regional expenditure. Yusriadi (2017) also found that the Revenue Sharing Fund partially had a significant effect on regency / city expenditure in Aceh. Likewise the results of Wulandari's (2014) research that Revenue sharing funds have a positive and significant effect on regional expenditure in the 2009-2011 period. The regional government that has a high $\mathrm{DBH}$, the expenditure for regional expenditure allocation is also higher.

$\mathrm{DBH}$ has a large portion of regional finance. This indicates that the regional government still has a large dependence on the central government in financing regional expenditure and expenditure. However, in the long run, this kind of dependency must be even smaller. According to Harahap (2009), various investments made by regional governments are expected to provide positive results, so that more independent local governments can take advantage of the potential and resources in their regions to be able to meet regional expenditure and not rely on the central government in terms of financing government spending and expenditure area.

Effect of Local Government Own Revenue (PAD), Revenue sharing Funds (DBH), and Capital Expenditures on Economic Performance of Regency / City in Bali Province. Based on the results of data analysis it is known that $\mathrm{PAD}, \mathrm{DBH}$, and capital expenditure have a positive and significant effect on the economic performance of regency / cities in Bali Province. This means that if PAD, DBH and capital expenditure increase, it will have an effect on improving economic performance significantly, and vice versa. The results of these studies are in accordance with Widyasari's (2013) study of the influence of PAD, DBH, DAU, and DAK on the regency / city economic growth (GRDP) in Central Java Province. From the results of this study it can be concluded that PAD and DAK have no significant effect on GRDP. While DBH and DAU have a significant effect on GRDP.

Effect of Local Government Own Revenue (PAD), Revenue sharing Funds (DBH), Capital Expenditures, and Economic Performance on Community Welfare of Regency / City in Bali Province. The results of data analysis show that PAD, DBH, capital expenditure, and economic performance of regency / cities in Bali Province have a positive and significant effect on community welfare. This means that, increasing PAD, DBH, capital expenditure, and economic performance of regency / cities in Bali Province, will have an impact on improving community welfare significantly. The results of this study are also supported by previous research which also shows results as in this study. Wardani (2018) conducted a study on the effect of regional assets, PAD, balance funds, and capital expenditure on the community welfare (HDI) in the Regency and City Governments of Central Java Province 2014-2016. The results of Wardani's research (2018) show that PAD has an effect on the 
human development index. While regional assets, balancing funds and capital expenditure have no effect on the human development index.

PAD plays an important role in improving the quality of human development in each regency and city. Increased Local Government Own Revenue will contribute to efforts to improve the welfare of the community, which in turn will be used to build and repair infrastructure for public needs such as improving facilities for supporting health, education and public facilities. PAD is the most important source of financing in supporting regional capacity in carrying out regional autonomy. In this context, PAD as a measure of regional own is highly expected as a source of funding for improving services and welfare for the community to build their regions including the quality of life of the people in the regions reflected in the human development index (HDI).

Local Government Own Revenue (PAD) in the era of regional autonomy should be the main basis for the region, so that regional dependence on the central government through balanced funds is decreasing and in the end the regions have the power to fulfill all their needs related to public service procedures. Whereas according to Law No. 33 of 2004 that PAD is income earned by regions collected under regional regulations in accordance with laws and regulations, consisting of regional taxes, regional levies, separated regional wealth management results and other legitimate PAD. The research conducted by Yanto et al. (2018) shows that local revenue has a significant effect on the human development index. In contrast to the research of Anggraini and Sutaryo (2015), it is proven that regional income does not affect the human development index.

Capital Expenditures are regional government expenditures whose benefits exceed one fiscal year and will add assets or wealth to the region and subsequently will add routine expenditures such as maintenance costs to general administration expenditure groups (Halim, 2004). The regional government allocates funds in the form of a capital expenditure budget in the APBD to add fixed assets. The research conducted by Yanto et al. (2018) shows the results of research that capital expenditure has an effect on the human development index.

Indirect Effects of Local Government Own Revenue (PAD), Revenue sharing Funds $(D B H)$ on Economic Performance Through Capital Expenditures and Economic Performance of Regency / City in Bali Province. Based on the results of analysts it is known that PAD indirectly has a significant effect on economic performance through capital expenditure of regency / city in Bali Province, meaning that the influence of PAD on subsequent capital expenditure will have a significant impact on economic performance. However, it is also known that indirect $\mathrm{DBH}$ does not have a significant effect on economic performance through capital expenditure. This shows that $\mathrm{DBH}$ does not have a significant impact on economic performance if through capital expenditure.

The results of this study have similarities with the research of Dewi and Budhi (2015) on the influence of PAD and DBH on economic growth through direct shopping in Bali Province. The results obtained indicate that the Local Government Own Revenue has a direct effect on Direct Spending, but the Revenue Sharing Fund does not directly affect Direct Spending. Furthermore, Direct Sharing and Expenditure Funds have a direct effect on economic growth, while Local government own revenue does not have a direct effect on economic growth. Then the Local government own revenue has an indirect effect on economic growth through Direct Spending, while the Revenue Sharing Fund does not have an indirect effect on economic growth through Direct Spending.

Regarding him above, Bose and Osborn (2007) found that government capital expenditure proved to be able to influence economic growth positively and significantly, where economic growth in the study was proxied through GDP. The results of the same study were also obtained by Chude and Chude (2013) which proved that capital expenditure had a positive effect on economic growth. This proves that the high realization of direct spending is an important indicator in supporting economic growth.

The results of data analysis show that PAD, DBH and capital expenditure indirectly have a significant effect on community welfare through the economic performance of regency 
/ cities in Bali Province. This means that in order for PAD, DBH and capital expenditure to have a significant impact on community welfare, it can be done through capital expenditure.

The results of this research have matched the research of Wijayanti and Darsana (2015) investigating the influence of PAD and DAU on community welfare through economic growth (study of Regency / Cities in Bali Province 2008-2013). The results of the analysis show that PAD and DAU have a significant positive effect on economic growth. PAD and DAU have no direct effect on people's welfare, while economic growth has a positive and significant effect on people's welfare. Economic growth is a variable that fully mediates in the influence of PAD and DAU on people's welfare.

Various efforts are designed and implemented by the local government solely in order to increase growth for the region itself and subsequently it is expected to have a positive impact on the welfare of its people. One of the efforts made by the regional government in achieving its objectives is the implementation of development as a form of decentralization. According to Dewi and Sutrisna (2014), states that public welfare is one of the final goals of the realization of an effective and efficient government in the framework of creating fiscal decentralization. Socio-economic development that reflects the welfare of the community in an area is expected to be realized by efforts made by the regional government (Akudugu, 2012). Efforts to implement development in each region are part of the implementation of regional autonomy. The implementation of regional autonomy is an attempt by the central government to give responsibility or authority to local governments in managing, regulating and managing their own households in accordance with the regulations in the laws and principles of regional autonomy.

\section{CONCLUSION AND SUGGESTIONS}

Local Government Own Revenue has a positive and significant effect on capital expenditure, but the Revenue Sharing Fund does not have a significant effect on capital expenditure of regency / city in Bali Province.

Original Regional Revenue, Revenue Sharing funds and capital expenditure have a positive and significant effect on the economic performance of Regency / Cities in Bali Province.

Regional Local Government Own Revenue, Revenue Sharing Funds, capital expenditure, and economic performance on the welfare communities of the Regency / City in the Province of Bali.

Local Government Own Revenue and Revenue Sharing funds indirectly have a significant effect on community welfare through capital expenditure and economic performance of regencies / cities in Bali Province.

Based on the results of the analysis and conclusions obtained, it is recommended that the regional government be more careful in allocating Revenue Sharing Funds, especially tax Revenue sharing Funds so that they are allocated for capital expenditure to support national development priority activities.

This research is only carried out in the province of Bali, so that these results cannot be thoroughly used as a reference for assessing welfare in other provinces in Indonesia. This study only focuses on variables that affect people's welfare, such as local revenue, capital expenditure, revenue sharing and economic performance. Future research can discuss or add other variables outside of this model such as quality of life, number of poor people, and the level of unemployment.

\section{REFERENCES}

1. Abel, Andrew B. And Ben S. Bernake. 2001. Macroeconomics. New York: Addison Wesley Longman, Inc.

2. Adiwibowo, Dian. 2005. Pengaruh Pembiayaan Pendidikan, Tingkat Pendidikan, Pertumbuhan Ekonomi and Kemiskinan di Jawa Tengah. Jurnal Economia, Volume 10, Nomor 2, Oktober 2014. 
3. Agus Sumanto and Effendie. 2015. The Effect of Government Capital Expenditure and Private Investment on Social Welfare. Journal of Economics and Sustainable Development ISSN 2222-1700 (Paper) ISSN 2222-2855 (Online) Vol.6, No.14, 2015. P 202-2015.

4. Ahmad, Yani. 2002. Hubungan Keuangan Antara Pemerintah Pusat and Daerah Di Indonesia. Jakarta: Raja Grafindo Persada.

5. Akudugu, Jonas Ayaribilla. 2012. Accountabillity in local Government revenue management: who does what?. Journal of Sustainable Development. Vol. 2(8), hal. 2232.

6. Anonim, 2003. Undang-Undang Nomor 17 Tahun 2003 tentang Keuangan Negara.

7. Anonim, 2004. Undang-Undang Nomor 32 Tahun 2004 tentang Pemerintahan Daerah.

8. Anonim, 2005. Peraturan Pemerintah Republik Indonesia Nomor 58 Tahun 2005 tentang Pengelolaan Keuangan Daerah.

9. Anonim, 2006. Peraturan Menteri Dalam Negeri Nomor 13 Tahun 2006 tentang Pedoman Pengelolaan Keuangan Daerah.

10. Anonim, 2009. Peraturan Menteri Dalam Negeri Nomor 25 Tahun 2009 tentang Pedoman Penyusunan APBD Tahun Anggaran 2010.

11. Anonim, 2010a. Peraturan Menteri Dalam Negeri Nomor 37 Tahun 2010 tentang Pedoman Penyusunan APBD Tahun Anggaran 2011.

12. Anonim, 2010b. Peraturan Pemerintah Nomor 71 Tahun 2010 tentang Standar Akuntansi Pemerintahan.

13. Anonim, 2011. Peraturan Menteri Dalam Negeri Nomor 22 Tahun 2011 tentang Pedoman Penyusunan APBD Tahun Anggaran 2012.

14. Anonim, 2012. Peraturan Menteri Dalam Negeri Nomor 37 Tahun 2012 tentang Pedoman Penyusunan APBD Tahun Anggaran 2013.

15. Anonim, 2013. Peraturan Menteri Dalam Negeri Nomor 27 Tahun 2013 tentang Pedoman Penyusunan APBD Tahun Anggaran 2014.

16. Anonim, 2014. Peraturan Menteri Dalam Negeri Nomor 37 Tahun 2014 tentang Pedoman Penyusunan APBD Tahun Anggaran 2015.

17. Anonim, 2015. Peraturan Menteri Dalam Negeri Nomor 52 Tahun 2015 tentang Pedoman Penyusunan APBD Tahun Anggaran 2016.

18. Anonim, 2016. Peraturan Menteri Dalam Negeri Nomor 31 Tahun 2016 tentang Pedoman Penyusunan APBD Tahun Anggaran 2017.

19. Anggraini, Tita and Sutaryo. 2015. Pengaruh Rasio Keuangan Daerah terhadap Indeks Pembangunan Manusia Pemerintah Provinsi di Indonesia, Jurnal IImiah Simposium Nasional Akuntansi XVIII, Tidak dipublikasikan, Medan.

20. Aris Setia Budi. 2017. Pengaruh Pendapatan Asli Daerah, Dana Perimbangandan Belanja Daerah Terhadap Indeks Pembangunan Manusia pada Pemerintah Kabupaten/Kota Di Jawa Tengah Tahun 2012-2014. Skripsi Jurusan Akuntansi Syariah Fakultas Ekonomi and Bisnis Islam Institut Agama Islam Negeri Surakarta.

21. Arsyad, Lincolin. 1999. Ekonomi Pembangunan. Edisi Keempat, Universitas Gajahmada. Yogyakarta: Bagian Penerbitan STIE YKPN.

22. Asmita, Fitrawaty, Dede Ruslan. 2017. Analysis of Factors Affecting the Human Development Index in North Sumatra Province. IOSR Journal of Business and Management (IOSR-JBM. e-ISSN: 2278-487X, p-ISSN: 2319-7668. Volume 19, Issue 10. Ver. VII. (October. 2017), PP 27-36.

23. Aziz, Asmaul. 2016. Pengaruh Karakteristik Pemerintah Daerah Terhadap Kinerja Keuangan Pemerintah Daerah. Jurnal EKSIS. Vol XI No 1.

24. Bastian, Indra, 2006. Akuntansi Sektor Publik. Jakarta: Salemba Empat.

25. Bose, N., Haque, M.E., and Osborn, D.R. 2007. Public Expenditure and Economic Growth: A Disaggregated Analysis for Developing Countries. The Manchester School. Vol. 75(5): 533-556.

26. Bungin, Burhan. 2001. Metodologi Penelitian Sosial, Format-format Kuantitatif and Kualitatif. Surabaya: Airlangga University Press. 
27. Chin, W. W. (1998). The Partial Least Squares Aproach to Structural Equation Modeling. Modern Methods for Business Research, 295, 336

28. Chopra, P.N. 1981. Micro Economics: Welfare Economics. New Delhi: Kalyani Publisher.

29. Christy, Fhino Andrea and Priyo Hari Adi.2009. Hubungan antara Dana Alokasi Umum, Belanja Modal and Kualitas Pembangunan Manusia.The 3rd National Conference UKWMS, Surabaya, 10 Oktober 2010

30. Darise, N. 2006. Pengelolaan Keuangan Daerah. Jakarta: Index.

31. Daryanto, Arief and Yundy Hafizrianda. Model-Model Kuantitatif untuk Perencanaan Pembangunan Ekonomi Daerah, Konsep and Aplikasi. Bogor: PT.Penerbit IPB Press, 2010.

32. De Fretes, Pieter N.2007. Analisis tentang Pengaruh Investasi Terhadap Pembangunan Ekonomi di Provinsi Papua. Jurnal Aplikasi Manajemen. Vol. 5 (1), 817.

33. Dedi Suprianto. 2016. Pengaruh Pendapatan Asli Daerah (Pad) Terhadap Belanja Modal Pemerintah Di Kabupaten Nagan Raya. Skripsi Program Studi Ekonomi Pembangunan Fakultas Ekonomi Universitas Teuku Umar Meulaboh, Aceh Barat.

34. Denni Sulistio Mirza, 2012. Pengaruh Kemiskinan, Pertumbuhan Ekonomi, and Belanja Modal Terhadap Indeks Pembangunan Manusia di Jawa Tengah tahun 2006-2009. EjounalJurusan Ekonomi Pembangunan, Fakultas Ekonomi, Universitas Negeri Semarang, Indonesia.

35. Dewi, N.W.N. and Budhi, M.K.S. 2015. Pengaruh Pendapatan Asli Daerah and Dana Bagi Hasil Terhadap Pertumbuhan Ekonomi Melalui Belnja Langsung di Provinsi Bali. E-Jurnal Ekonomi Pembangunan Universitas Udayana. Vol. 4, No.11, hal.1391-1420.

36. Dewi, Putu Ayu Krisna and Sutrisna, I Ketut.2014.Pengaruh kemandirian Keuangan Daerah and Pertumbuhan Ekonomi terhadap Indeks Pembangunan Manusia di Provinsi Bali. E-Jurnal Ekonomi Pembangunan, Vol 4 No. 1, tahun 2014. Universitas Udayana.

37. Dulahi Darman. 2016. "Pengaruh Pajak Daerah and Dana Alokasi Umum Terhadap Sisa Lebih Pembiayaan Anggaran (Survey Pada Kabupaten/Kota Di Provinsi Sulawesi Tengah)". e-Jurnal Katalogis, Volume 4 Nomor 6, I SSN: 2302-2019.

38. Dumairy. 1997. Perekonomian Indonesia. Jakarta: Penerbit Erlangga.

39. Faguet, J.P.2000. Does Decentralization Increase Responsiveness to Local Need ? Evidence from Bolivia, London: School of Economic.

40. Febriansya Abdullah. 2013. Pengaruh Pendapatan Asli Daerah, Dana Alokasi Umum, and Alokasi Khusus Terhadap Kinerja Keuangan Pemerintah Daerah Kabupaten/Kota se-Sumatera Bagian Selatan, e-Journal.unp.ac.id, ISSN 2303-0356

41. Ferina, I.K., Burhanudin, and Trisnawati, N.A. 2016. "Efektivitas Realisasi and Serapan Anggaran Pendapatan and Belanja Daerah Pada Pemerintah Kabupaten Ogan Komering Ilir Tahun 2013-2015". Jurnal IImiah Manajemen Bisnis and Terapan. Tahun XIII No 2.

42. Fitroh, M., and Putra. I. S., 2016. "Pengaruh Sisa Lebih Perhitungan Anggaran (Silpa) Terhadap Penetapan Jumlah Anggaran Tahun Berikutnya”. JurnalPETA. e-ISSN 25282581 Vol. 1 No. 1. 1-19

43. Ghozali, Imam, 2011. Structural Equation Modeling Metode Alternative dengan Partial Least Square. Semarang: Badan Penerbit Universitas Diponogoro.

44. Gregory Paul. R and Robert C Stuart. 1992. Comparative Economic 'System. Fourth Edition. New Jersey: Houghton Meffin Company.

45. Guritno, Mangkoesoebroto, 2012. Ekonomi Publik, Edisi Kelima. Yogyakarta: BPFE Yogyakarta.

46. Hakim, A. R. 2016. "Identifikasi Faktor-Faktor Yang Menyebabkan Sisa Lebih Perhitungan Anggaran (Studi Kasus Pada Pemerintah Kota Yogyakarta and Pemerintah Kabupaten Kulon Progo)". Tesis. Universitas Gadjah Mada.

47. Halim, Abdul. 2004. Akuntansi Keuangan Daerah. Jakarta: Salemba Empat. 
48. 2012. Manajemen Keuangan Sektor Publik Problematika Penerimaan and Pengeluaran Pemerintah". Jakarta: Salemba Empat.

49. Hammond, George W and Tosun, Mehmet S, 2009. The Impect of local Decentralization on Economic Growth: Evidence from U.S. Counties. IZA Discussion Papper No. $45-74$.

50. Harahap, Alfan. 2009. Pengaruh Dana Bagi Hasil Sumber Daya Alam terhadap belanja modal pada kabupaten and kota di Sumatera Utara. Skripsi, Universitas Sumatera Utara, Medan.

51. Hasan, H. A., Haryadi, B., and Rimawati, Y. 2015. "Jalan Panjang Menuju Pengesahan Apbd: Berdasarkan Sudut Pandang Agency Theory”. Jurnal Keuangan and Perbankan. Vol. 12, No.1.

52. Hasanudin, I. 2015. "Apa Itu Dana Bagi Hasil Pajak". (https://ep507.blogspot.co.id/2015/05/apa-itu-dana-bagi-hasil-pajak.html). Diakses 10 Desember 2017.

53. Herlina, Rahman, 2005. Pendapatan Asli Daerah. Jakarta: Arifgosita.

54. Iswahyudin. 2016. "Pengaruh Belanja Modal, Belanja Barang and Jasa Terhadap Sisa Lebih Pembiayaan Anggaran (Silpa) Kabupaten/Kota Di Sulawesi Tengah". E Jurnal Katalogis, Volume 4 Nomor 6.

55. Izudin, H., Syaparudin., and M. Syamsudin. H. 2013. "Kinerja Keuangan Daerah and Hubungan Dengan Silpa Di Kabupaten Bungo". Jurnal Perspektif Pembiayaan and Pembangunan Daerah. Vol. 1 No.1.

56. Juanda. 2008. Hukum Pemerintah Daerah. Bandung: Alumni.

57. Kerlinger, Fred. N. 2002. Asas-asas Penelitian Beharioral. Edisi Ketiga (Penerjemah: Landung R. Simatupang). Yogyakarta: Gadjah Mada University Press.

58. Magdalena, M. 2013. "Perbandingan Indikator Kinerja Keuangan Pemerintah Provinsi Di Indonesia". Jurnal MODUS. Vol. 25 (1). 91-106

59. Mahendra Putra, Putu Gde and I Gusti Ketut Agung Ulupui. 2015. Pendapatan Asli Daerah, Dana Alokasi Umum, Dana Alokasi Khusus, Untuk Meningkatkan Indeks Pembangunan Manusia E-Jurnal Akuntansi Universitas Udayana 11.3 (2015) ISSN: 2302 - 8556: 863-877

60. Mamesa, DJ. (1995). Sistem Akuntansi Keuangan Daerah, PT Gramedia Pustaka, Jakarta.

61. Mc.Eachern, William A. 2000. Ekonomi Makro: Pendekatan Kotemporer (diterjemahkan: Sigit Traiandaru). Jakarta: Salemba Empat.

62. Mehrota, Santosh. 2001. Democracy, Decentralization and Acces to Basic Service: An Elaboration on Sen's Capability Approach. Senior Economic Adviser, Cambridge, UNICEF Innocenti Research Centre Florence.

63. Mohamad Azis. 2016. Pengaruh Dana Bagi Hasil Bukan Pajak/Sumber Daya Alam Dana Alokasi Umum (Dau) and Pendapatan Asli Daerah (Pad) Terhadap Pertumbuhan Ekonomi Di Kabupaten Malinau. INOVASI: Jurnal Ekonomi Keuangan, and Manajemen, Volume 12, (1), 2016 ISSN print: 0216-7786, ISSN online: 2528-1097. P $49-63$.

64. Mulyono, Y. 2017. "Jokowi Ancam Sanksi Kepala Daerah yang Serapan APBDnya Rendah".(https://news.detik.com/berita/d-3598051/jokowi-ancamsanksi-kepala-daerahyang-serapan-apbd-nya-rendah. Diakses 15 Desember 2017.

65. Nazarullah. 2011. Pengaruh Dana Bagi Hasil Migas and Pendapatan Asli Daerah Terhadap Belanja Daerah di Kabupaten Aceh Utara. Skripsi. Aceh Utara.

66. Novia Nur Putriasani, 2010. Pengaruh Pendapatan Asli Daerah (PAD) Terhadap Belanja Modal and Implikasinya Pada Belanja Pemeliharaan (Studi Pada Pemerintah Kota Cirebon). E-JurnalUniversitas Komputer Indonesia.

67. Noviwijaya, A. \& A. Rohman. (2013). "Pengaruh Keragaman Gender and Usia PejabatPerbendaharaan Terhadap Penyerapan Anggaran Satuan Kerja (Studi Empiris pada Satuan Kerja Lingkup Pembayaran KPPN Semarang I)". Journal Diponegoro of Accounting. Vol. 2 (3): 1-10. 
68. Nurcholis, Hanif. 2007. Teori and Praktik Pemerintahan and Otonomi Daerah, Jakarta: Grasindo.

69. Pradata, Kefas Caesar. 2015.Pengaruh Pendapatan Asli Daerah (PAD) and Dana Alokasi Umum (DAU) Terhadap Belanja Modal Di Jawa Tengah Tahun 2011-2013. Skripsi. Yogyakarta: Universitas Negeri Yogyakarta.

70. Priambudi, Wimpi. 2017. Pengaruh Pendapatan Asli Daerah and Dana Alokasi Umum Terhadap Belanja Modal pada Kabupaten and Kota di Pulau Jawa Tahun 2013. Jurnal Nominal, Vol. 1, No.1, hal. 136-147.

71. Rahardja, Pratama and Mandala Manurung, 2001. Teori Ekonomi Makro, Suatu Pengantar. Jakarta: Lembaga Penerbit Fakultas Ekonomi Universitas Indonesia,

72. Rosyid, Moh. Pengaruh Dana Alokasi Umum, Dana Alokasi Khusus, Dana Bagi Hasil and Pendapatan Asli Daerah Terhadap Belanja Daerah Kabupaten/Kota Provinsi Sulawesi Tengah. eJurnalKatalogis, Volume 6 Nomor 1Januari 2018 hlm 204-216 ISSN: 2302-2019.

73. Samuelson, Paul A and Nordhaus, William D. 1995. Makro Ekonomi. Jakarta: IKAPI.

74. Saragih, Juli Panglima. 2003. Desentralisasi Fiskal and Keuangan Daerah dalam Otonomi. Jakarta: Gahalia Indonesia.

75. Simamora, S. 2014. "Pengaruh Sisa Lebih Perhitungan Anggaran (Silpa), Penerimaan and Pengeluaran Pembiayaan Terhadap Belanja Daerah: Dalam Presfektif Teoritis". Jurnal Riset Akuntansi and Bisnis. Volume 14 No.2

76. Sondakh, Glenn Yericko, Agnes L. Ch. P. Lapian, Hanly F. Dj Siwu, 2017. Pengaruh Belanja Modal Pemerintah Daerah and Investasi Swasta Terhadap Kesempatan Kerja and Pertumbuhan Ekonomi Di Kota Manado (Tahun 2006-2015). JurnalBerkala IImiah Efisiensi. Volume 17 No. 01 Tahun 2017. Ilmu Ekonomi Pembangunan, Fakultas Ekonomi and Bisnis Universitas Sam Ratulangi, Manado, Indonesia P 146 - 156

77. Spiegel, Henry William. 1991. The Growth of Economic Thought, Third Edition. London: Duke University Press.

78. Sugiyono. 2009. Metode Penelitian Bisnis (Pendekatan Kuantitatif, Kualitatif, and R\&D). Bandung: Alfabeta.

79. Suharna, I. 2015. "Analisis Sisa Lebih Perhitungan Anggaran (SiLPA) pada APBD Pemerintah Kabupaten Bulungan Propinsi Kalimantan Utara Tahun Anggaran 2007 s.d. 2013". Tesis. Universitas Gajdah Mada. Yogyakarta.

80. Sukirno, Sadono, 2001. Pengantar Makroekonomi. Jakarta: PT Raja Grafindo Persada.

81. Sukirno, Sadono. 2006. Ekonomi Pembangunan: Proses, Masalah, and Dasar Kebijakan. Jakarta: Prenada Media Group.

82. Sumanto, Agus and Effendie. The Effect of Government Capital Expenditure and Private Investment on Social Welfare. Journal of Economics and Sustainable Development Vol. 6, No. 14, 2015.

83. Suwandi, Made, 2000. Agenda Strategis Penataan Otonomi Daerah (Sebagai tindak janjut UU No. 22 and UU No. 25 tahun 1999), Makalah Work Shop Otonomi Daerah, Kerjasama LPEM- UI and IRIS Jakarta.

84. Suyana, Utama. 2012. Aplikasi Analisis Kuantitatif. Buku Ajar. Denpasar: Fakultas Ekonomi Universitas Udayana.

85. Syahputra, Indra. 2010. Pengaruh Pendapatan Asli Daerah, Dana Bagi Hasil, Dana Alokasi Umum Terhadap Belanja Daerah Kabupaten/kota di Provinsi Sumatera Utara. Jurnal IImu Sosial.

86. Syarifin Pipin, Jubaedah Dedah. (2005). Hukum Pemerintahan Daerah. Bandung: Pustaka Bani Quraisy.

87. Syukiy. 2012. "Varians Anggaran Pendapatan and Varians Belanja DaerahSebuahPengantar". ttps://syukriy.wordpress.com/ 2012/10/16/ varians anggaranpendapatan-daerah). Diakses 20 Desember 2017.

88. Todaro, Michael P and Stephen C. Smith, 2002. Pembangunan Ekonomi di Dunia Ketiga, Buku 1 Edisi Kesembilan. Jakarta: Penerbit Erlangga.

89. Travers, Tony (2012) Local Government's Role In Promoting Economic Growth: Removing Unnecessary Barriers To Success. Reseach Online of The London School 
of Economics and Political Science. This version available at: http://eprints.Ise.ac.uk/47842/ and originally available from Local Government Association.

90. Triyanto, Danang, Setyo Tri Wahyudi, and Candra Fajri Ananda, 2017. The Effect of Capital Expenditure on Local Own-Source Revenue: Study In East Java Indonesia. JournalJEKT 10 [2]: 137-144.

91. Victor, Pekpekai. 2003. Peranan anggaran pendapatan and belanja daerah (APBD) terhadap indeks pembangunan manusia (IPM): Studi kasus Provinsi Papua 1990-1999. Universitas Gajah Mada. Yogyakarta.

92. Wardani, Niken Kusuma. 2018. Pengaruh Aset Daerah, PAD, Dana Perimbangan, and Belanja Modal Terhadap Indeks Pembangunan Manusia (Studi Empiris Pada Pemerintah Daerah Kabupaten and Kota Provinsi Jawa Tengah Tahun 2014-2016). Skripsi. Surakarta: Universitas Muhammadiyah.

93. Warsito. 2001. Hukum Pajak. Jakarta: PT. Rajawali Grafindo Persada.

94. Wicaksono, K., A. 2015. "Dana Bagi Hasil: Basis Penyalurannya Diubah. (http://finansial.bisnis.com/read/20150909/10/470530/javascript). Diakses1 Januari 2018.

95. Widyasari, Nurul. 2013. Pengaruh Pendapatan Asli Daerah (PAD), Dana Bagi Hasil (DBH), Dana Alokasi Umum (DAU), Dana Alokasi Khusus (DAK) Terhadap Pertumbuhan Ekonomi (PDRB) (Studi Empiris Kabupaten/Kota di Provinsi Jawa Tengah). Naskah Publikasi. Surakarta: Fakultas Ekonomi and Bisnis, Universitas Muhammadiyah Surakarta.

96. Wijayanti, N.K.H. and Darsana, I.B. 2015. Pengaruh Pendapatan Asli Daerah and Dana Alokasi Umum Terhadap Kesejahteraan Masyarakat Melalui Pertumbuhan Ekonomi (Studi Kabupaten/Kota di Provinsi Bali Periode 2008-2013). E-Jurnal Ekonomi Pembangunan Universitas Udayana. Vol. 4, No. 3, hal. 1164-1193.

97. Williantara, Gede Ferdi, and Gusti Ayu Budiasih. 2016. Pengaruh Pendapatan Asli Daerah (PAD), Dana Alokasi Umum (DAU), Dana Alokasi Khusus (DAK), and Dana Bagi Hasil (DBH) pada Indeks Pembangunan Manusia (IPM). E-Jurnal Akuntansi Universitas Udayana Vol.16.3. September (2016) ISSN: 2302-8556: pp 2044-2070.

98. Winarni. N.S. 2013. "Pengaruh Faktor-Faktor dalam Aspek Manajemen Keuangan Daerah terhadap Sisa Lebih Perhitungan Anggaran pada Pemerintah Kota Tarakan". Tesis. Universitas Gadjah Mada Yogyakarta.

99. World Bank, 2001. World Development Report 2000/2001: Attacking Poverty. New York: Oxford University Press.

100. Wulandari, Yolanda, 2014. Pengaruh Dana Bagi Hasil Terhadap Belanja Daerah Pada Kabupaten and Kota Di Indonesia. Skripsi: Program Studi Akuntansi Fakultas Ekonomi Universitas Negeri Padang.

101. Yanto, E., Ridwan, and F. Vitayanti. 2018. Pengaruh Pendapatan Asli Daerah and Belanja Modal Terhadap Indeks Pembangunan Manusia. E-Jurnal Katalogis. Vol. 6, No. 2.

102. Yinqiu Lu and Tao Sun, 2013. Local Government Financing Platforms in China: A Fortune or Misfortune? IMF Working Paper WP 13/243.

103. Yolanda Wulandari. 2014. Pengaruh Dana Bagi Hasil terhadap Belanja Daerah pada Kabupaten and Kota di Indonesia. Skripsi Program Studi Akuntansi Fakultas Ekonomi Universitas Negeri Padang.

104. Yusriadi, Sri Mulyati. 2017. Dana Bagi Hasil and Dana Alokasi Umum Terhadap Belanja Daerah pada Provinsi Aceh. AGREGAT: Jurnal Ekonomi and Bisnis, Vol. 1, No. 2, hal. 211-220.

105. Yutamana Slamet, Ketut. 2004. Pengaruh Alokasi Belanja Publik and Belanja Rutin terhadap Pertumbuhan Ekonomi Kabupaten Badung, Tesis Program MEP FE Unud.

106. Zarinah, M. 2016. "Pengaruh Perencanaan Anggaran and Kualias Sumber Daya Manusia Terhadap Tingkat Penyerapan Anggaran Satuan Kerja Perangkat Daerah Di Kabupaten Aceh Utara". Jurnal Magister Akuntansi. Volume 5, No. 1. 